\title{
A Study of Rancidity of Fish Sold In Mubi Markets, Adamawa State, Nigeria
}

\author{
Waindu, C and Jamala, G.Y* \\ College of Agriculture, Ganye, Adamawa State, Nigeria
}

\begin{abstract}
This study was carried out on the rancidity situation of fish sold in Mubi markets, Adamawa State Nigeria. Standard methods were used in data accumulation. Fish market at Mubi was visited during the month of July and August and the smoked, dead, dried and frozen fish were sampled and analyzed for peroxide value. There was low association between the smoke and dead Clarias and Tilapia and between the dried and frozen fish (Mormyrus rume and mackerel) sold in the markets in the month of July. Though the paired t-test value of $t=10.524 \mathrm{df}=1, P=0.051$ was recorded of smoke and dead fish and $t=-11.211 \mathrm{df}=1$ was recorded for dried and frozen fish. The association between the peroxide values of smoked and dead fish sold in the market in the month of August was $r=0.8, P=0.001$ and frozen $r=0.57 P=0.01$ and the paired $t$-test association if $t=-13.285$ $P=0.001$ shows a significant difference. The smoked and dead fish have correlation value of $r=0.7 P=0.01$ with $t$-value of $t=-10.54, P=0.10$ showing a significant difference between their peroxide value. There was correlation $r=0.6$ between the smoked and dead fish with $t$-value of $t=28.08, P=0.028$ showing a significant difference between peroxide values of Clarias in the market. The dried and frozen fish peroxide values were not significantly different as well as the smoke and dead fish. The same relationships were recorded for smoked and dead Clarias and Tilapia, dried Mormyrus rume and frozen Mackerel. Based on the result of this study peroxide values varied with fish species and size. The dead fish had higher values than those processed. The health problems associated with rancid fish are highlighted.
\end{abstract}

Keywords: Rancidity, Peroxide, Fish, Frozen, Dead, Market

\section{Introduction}

Food is one of the basic necessities of life; it is consumed to provide the body with nutrients. The nutrients play the important role of energy supply, repair of worn tissues, synthesis of new tissue and maintenance of several other functions (Okaka and Okaka, 2001)

Fish are a major source of food for humans providing a significant portion of the protein intake in the diet of a large portion of the people in the developing countries as it is the only source of cheaper animal protein with little or no religious rejection and it has advantage over pork or beef (Eyo, 2002). Fish is consumed as food and are important contributor to the national economy being that it is always readily available in most markets either as fresh, smoked, dried canned, chilled or frozen (Talabi and Igbinosun, 1975)

To increase the food supply as much as 10 to 20 percent is by reducing post harvest losses. It is estimated that 25 percent or more of the world's food production is lost after harvesting and the losses are higher in developing countries of Africa, Asia, and Latin America than in the developed or industrial nations (Okaka and Okaka, 2001).

These postharvest losses have created wider gap between the demand and supply of fish in Nigeria. The estimated fish demand in Nigeria is 1.085 million tones using a population figure of 88.5 million based on per capital consumption of $12.0 \mathrm{~kg}$ regarded a global basis, as adequate for normal healthy growth. But unfortunately total domestic fish production of which the artisanal and industrial sectors averagely contributed $96 \%$ and $4 \%$ respectively from $1985-1987$. The demand for fish in Nigeria at present is about 756,000 tones out of which about 373,044 tones (49.5\%) is imported (Okorie, 2003)

It is therefore, important to understand the causes of spoilage and how to prevent these causes so as to minimize losses. Since fish are most important animal protein in the diet of many people in Nigeria. Spoilage of fish may take place before, during, or after processing. The sooner any preventive measures are taken after capture of fish, the greater the chance of reducing post harvest losses so as to increase fish availability to meet the demand of the growing population (Eyo,1983). It has been reported that $10 \%$ by weight of the world fish catch is lost through poor handling, processing and distribution (Madison et al., 1998). A high proportion of Artisanal catches fail to reach market in their prime form (fresh) due to the long distance. This is lack of adequate fish handling. Preservation and processing methods contribute significantly to the low supply of fish to poor rural dwellers. These postharvest losses exacerbate the problem of insufficient supply of fish in Nigeria (Osuji, 1985).

For the fact that post harvest spoilage has hindered the even supply of fish protein to Nigerians, the need to preserve fish for better shelf-life, good flavor as well as creation of employment opportunity became 
imperative, being that fish is one of the most perishable food staples. Fish spoil very quickly because of intrinsic and extrinsic factors. The high ambient temperature in the tropics hastens fish spoilage by accelerating the activities of bacteria enzymes and chemical oxidation of fat in fresh (Eyo, 2001). There are many variables that contributes to the unique permissibility of fish flesh (tissue compositions) in the case of fatty fish, spoilage can be non-microbiological, fish lipids contain high proportion of polyunsaturated fatty acids, which are more reactive chemically than the largely saturated fats that occur in mammalian meat. This makes fish far more susceptible to development of oxidative rancidity (Adams and Mass, 1989).

The usefulness of fish in alleviating malnutrition is well known in Nigeria, attempts must be made to increase the domestic fish production to meet demand. This will require stepping up the total catch through proper management of resources and improving handling, preservation, processing and utilization of the catch to minimize losses from wastage thus by evolving efficient fish preservation and processing fish for food supply are not lost to physical, chemical or biological forces (Okaka and Okaka, 2001).

\section{Fish Spoilage}

In most case there are critical microbiological factors that influence fish spoilage such as water, temperature, acidity, oxygen and inhibitory substances. Since the minimum water activity requirements of normal bacteria, yeast and mould are 10,91, 0.88; While micro-organism can cause spoilage at temperature range of $10^{\circ} \mathrm{C}$ and $70^{\circ} \mathrm{C}$ in terms of acidity when the $\mathrm{pH}$ is neutral it favours the growth of bacteria, slight acidity favours yeast and acidity mould can tolerate. The oxygen exerts selectivity effect on microbial population either aerobic or anaerobic bacteria (Ugwu and Mgbenka, 2006).

Therefore, the spoilage as the result of a whole series of complicated changes in the dead fish's tissue by its enzymes, bacteria and chemical changes. This natural process is irreversible and this spoilage continues before, during or after processing unlike the mammalian muscle which does not spoil readily (Fison, 1992). Fish fats and oils can become rancid, hence not fit for human consumption.

\section{Factors causing fish spoilage}

These are some of the factors that could be considered

1. Activity of Micro-organism such as bacteria, moulds, and yeasts.

2. Deterioration through chemical processes such as break down of oils and fats (described as rancidity), and enzymic activity.

3. Attack by insects such as blow flies, beetles and various scavenging animals such vermins (Haruna, 2003).

4. Through contamination from people (germs on skin cuts on hands) Soil, dust, Sewage, Surface water manure and also by poor handling, use of poorly clean apparatus and contamination after a preservation treatment has been carried out example fish kept in dirty basket (Wageningen, 2004)

When a fish dies the process of deterioration sets in. This is an irreversible natural process and the preservation principle is to slowdown the deterioration process so as to maintain the overall quality and storage life of the product. The sooner, the preservation process are begun after the fish capture, the greater the chance of reducing post harvest losses (Haruna, 2003).

To achieve this it is expedient to control the factors that influence the agents such as chemical deterioration influence of insets and vermin damage. The factors include the following.

1. Good handling practices on board fishing vessels and at landing sites such practice include good hygiene removal of guts and gills, washing and cleaning with clean water

2. Rapid and proper processing procedure, such procedures, include reducing the moisture content of the fish, reducing the temperature through use of ice and shade, cooking, lowering of PH by creating acid conditions such as fermentation.

3. Protection from insect and vermin attack.

4. Effective packaging, storage and transportation.

\section{Rancidity}

Spoilage is caused by reactions in the fat of fish giving rise to unpleasant odors and flavors. This spoilage is generally called rancidity; fish oil is more liable to spoilage than other oils due to the greater number of unsaturated fatty acids as shown by the lower saponification number and higher iodine value. The greater the degree of unsaturation the greater the tendency for rancidity, the biochemical change to the production of rancid flavor and odor can best be understood by examining the mechanism of the reactions that give rise to chemical rancidity (Eyo, 2001). 


\section{Material And Methods}

Study area: The research was carried out at the Department of fisheries and Aquaculture wet and dry laboratory, Adamawa State University, Mubi, Nigeria, The study area is located between latitude $9^{\circ} 55^{\prime}$ and $10^{\circ}$ $45^{\prime}$ North and longitude $13^{\circ}$ and $13^{\circ} 5^{\prime}$ East, with population of about 280,009 (Population Census, 2006).

\section{Specimen collection}

The specimens (Fishes) were bought from Mubi market. Dead spoiled and processed spoiled fishes. The fresh dead spoiled fish serve as control experiment while the processed spoiled fishes are used as the treatment.

The specimens used are Cat fish (Clarias gariepinus) both dead and processed spoiled fishes, as well as Tilapia and Mormyrus rume. The spoiled frozen fish (Mackerel) was also used as they are the most only available fish species sold in the market. The study was carried for two months.

\section{Determination of peroxide value (Pv)}

Peroxide value $(\mathrm{Pv})$ measures the degree of lipid oxidation in fats and oils but not their stability. Peroxide value is defined as the mill equivalent (meq) of peroxide or hydro peroxide groups that are the initial products of lipid oxidation (Suzanna, 1994).

\section{Procedure}

5.0 grams sample was dissolved in $30 \mathrm{ml}$ of glacial acetic and-chloroform. $0.5 \mathrm{~m}$ of saturated $\mathrm{Kl}$ was added and $\mathrm{l}_{2}$ was liberated by reaction with peroxides and was titrated with standardized sodium sulphate using starch indicator peroxide value (pv) was calculated as follows.

$\mathrm{ROOT}+\mathrm{KIH}+$ Heat $\mathrm{ROH}+\mathrm{KOH}+\mathrm{I}_{2}$

$\mathrm{I}_{2}+$ Starch $-2 \mathrm{Na}_{2} \mathrm{~S}_{2} \mathrm{O}_{3} 2 \mathrm{Na}_{2} \mathrm{~S}_{2} \mathrm{O}_{6}+\mathrm{Starch}+\mathrm{Na} 1$

Peroxide Value (meq. Peroxide $1 \mathrm{~kg}$ fat)

$=\underline{S-B \times N \times 1000}$

Sample wt $(y)$

Where

$\mathrm{S}=$ Sample titration

$\mathrm{B}=$ Blank titration

$\mathrm{N}=$ Normality of $\mathrm{Na}_{2} \mathrm{~S}_{2} \mathrm{O}_{3}$ solution.

Statistical analysis

Data generated were subjected to t-test and correlation using to ascertain the significance level $\mathrm{P} \leq 0.05$ using SPSS ver. 13.02006 package.

\section{Results and Discussion}

The smoked fish sold in the month of July have mean peroxide value of $9.16 \pm 0.40 \mathrm{mg} / \mathrm{kg}$ while the dead fish have $18.3 \pm 0.35 \mathrm{mg} / \mathrm{kg}$ (Table 1). There was a low association of $\mathrm{P}=0.01$ between the smoked and dead fish sold in the studied market in the month of July. Though the paired t-test value of $t=10.524 \mathrm{df}=2 ; \mathrm{p}=$ 0.051 showing a significant difference between the peroxide value of the smoked and death fish sold in the market of Mubi.

In the month of August the smoked fish have mean peroxide value of $8.95 \pm 0.347 \mathrm{mg} / \mathrm{kg}$ while dead fish have $21.41 \mathrm{mg} / \mathrm{kg}$. The association between the peroxide values of smoked and dead fish sold in Mubi market in the month of August was $\mathrm{P}=0.60$ and the paired $\mathrm{t}$-test was $\mathrm{t}=-7.873$. The smoked Clarias sold at the market have a peroxide value of $9.16 \mathrm{mg} / \mathrm{kg}$ against $8.055 \mathrm{mg} / \mathrm{kg}$ recorded from smoked Tilapia. The dead Clarias have peroxide value of $18.300 \pm 0.55 \mathrm{mg} / \mathrm{kg}$ while dead Tilapia have $24.79 \pm 0.27 \mathrm{mg} / \mathrm{kg}$. The dead Clarias and Tilapia have correlation $\mathrm{p}=0.001$ and the paired t-test value of $\mathrm{t}=10.54, \mathrm{p}=0.10$ which denotes, significant difference between the two fish.

The smoked and dead tilapia have correlation value of $r=0.061, p=0.007$ showing a significant difference between the peroxide value of smoked and dead tilapia sold at Mubi market. There was low correlation $r=0.100$ between the peroxide value of smoked and dead Clarias with $t$-value of $t=28.08$ and $p=0.002$ showing a significant difference between the peroxide value of Clarias in the market.

The smoke Clarias and Tilapia peroxide value are significantly different. The same relationship was recorded for dead Clarias and Tilapia with correlation of $r=-1.00 \mathrm{p}=0.001$ from the values, it indicates that the Clarias and Tilapia have good relationship which are not significantly different to each other. 


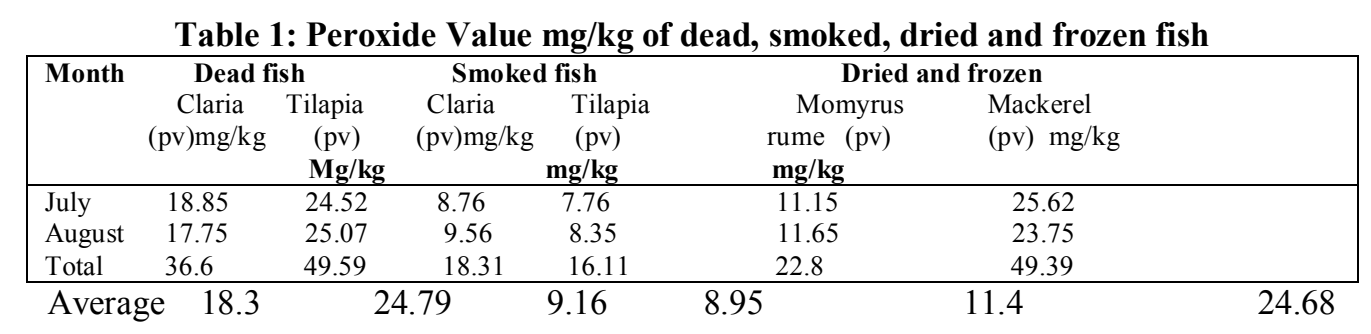

\section{Discussion}

In a study conducted by Eyo, (2001), shows that it is not the time fish was sampled but rather the species and the method of processing/preservation of the fish that really affect rancidity or setting in of spoilage. The fish that is smoked was reported to have low peroxide value as shown in Table 1 and for smoked Clarias and smoke Tilapia as well as dried Mormyrus rume and frozen Mackerel. Although higher peroxide value were from Clarias $(9.16 \mathrm{mg} / \mathrm{kg})$ against a lower value of $8.95 \mathrm{mg} / \mathrm{kg}$ from Tilapia while the frozen Mackerel has higher peroxide value of $24.68 \mathrm{mg} / \mathrm{kg}$ against a lower value of 11.40 from dried Mormyrus rume. This fact remains as Clarias was noted to contain more fatty than Mormyrus rume.

The highly unsaturated fatty acid found in fish lipid make them to be very susceptible to oxidation the primary oxidation products are the lipid hydroperoxides and the peroxide produced by the auto catalytic mechanisms affect the flavor and tastes of the fish (Huss, 1995)

The oxidation reaction though catalytic reaction has been shown by this study to occur faster in dead tissue than the processed fish. This is in line with the report of FISON (1992) that after fish dead there are series of complicated changes brought about in the dead fish tissue by its own enzymes, bacteria, and chemical changes. If the changes are not controlled this natural changes are irreversible and the preservation principle is to slow down the deterioration, being that the lipid hydrogenised break down with time and a low peroxide value at a certain point during the storage of product can indicate both an early phase of oxidation and late stage of severally oxidized product, where most hydro peroxide have been broken down.

The low peroxide value recorded in the smoked fish could have been as a result of low moisture content in the smoked fish (Ugwu and Mbenka, 2006). The onset of fish spoilage could be noticed by peroxide production in fish as well as the influence by the rate at which oxidation occurred in the fish, Clarias been the hardy fish that could survive in low dissolve oxygen have the tendency to withstand spoilage and stress. However stress during handling increase metabolic activities in fish when it happens with fish like Tilapia, Mormyrus rume and Mackerel, this accumulated and increases peroxide production, hence higher peroxide value will be recorded in dead Tilapia, frozen Mackerel and dried Mormyrus rume above dead Clarias. Besides the physiological contribution of stress, biological composition of the gut could also be a factor increasing peroxide value in Tilapia, Mackerel and Mormyrus rume which their feed habit differs from Clarias.

\section{Conclusion}

From this result it could be concluded that the processed/preserved fish generally has lower peroxide value than unprocessed (dead) fish and that processed fish will be more stable than the unprocessed/preserve fish. The dead fish sold in the market were rancid fish by the consumers.

It is important to note that good hygiene from onset of fishing to handling of fish caught will reduce the onset of spoilage which could be a key factor in peroxide production and oxidation of lipid in fish. The findings of this study revealed that Clarias and Mackerel spoil faster than Tilapia and Mormyrus rume, due to higher fatty acid content when compared to Tilapia and Mormyrus rume.

\section{References}

[1]. A.A. (2001). fish processing technology in the tropic, University of Ilorin Press Nigeria pp. 8, 37-103

[2]. Fison (1992). conference proceeding of the $10^{\text {th }}$ annual conference Abeokuta Fison publisher Victoria Island Lagos pp20-35

[3]. Haruna A. B. (2003). Aquaculture in the tropics theory and practice, Alhassan publishers Abuja 210-216

[4]. Huss, H. H. (1995). Quality Changes in Fresh fish FAO fisher's Technical paper 34-8-660

[5]. Karl F. Lagler, John E. Bench, Robert R, Miller (1977). Ichthyology John Willey Sons publisher USA pp1-8

[6]. Madison A. Machell, S. and Adams L. (1998). Fish processing food cycle technology source books. Intermediate technology publications Southampton Ro London pp, 235-236

[7]. Okaka Jod, Okaka A. N. C. (2001). Foods, composition spoilage self-life extension keyboard point computer Asta, Enugu pp 7593.

[8]. Osuji F. N. C (1985). the influence of traditional handling methods on the quality of processed fish in Nigeria University of Ibadan, Nigeria Handling processing and marketing of tropical fish held on London $5^{\text {th }}-9^{\text {th }} \mathrm{July}$, 1976 tropical products institute pp $319-322$.

[9]. Ugwu L. C. Mgbenka B. O (2006). Fisheries and wild life management a systematic approach Jones communication ogue new layout, Enugu, Nigeria pp 238-247 